\title{
THE SINISTER STEEPLES OF ALEXANDER NORTH
}

\author{
by Eric Ratcliff
}

(with 15 plates)

Ratcliff, E. 2017 (6:xii): The sinister steeples of Alexander North. Papers and Proceedings of the Royal Society of Tasmania 151: 65-78. https://doi.org/10.26749/rstpp.151.65 ISSN 0080-4703. Albion House, 153-155 George Street, Launceston, Tasmania 7250, Australia. Email: eric.ratcliff.albion@gmail.com

Alexander North (1858-1945), who practised chiefly in Tasmania, was an outstandingly original architect during the stylistic period in Australia now commonly called Federation. His work includes features that represent an extreme expression of established forms, and draws attention to some inadequately explained characteristics of the period. Prominent among these is a series of church spires that North designed in Tasmania between 1893 and 1927, which evoke peculiar associations in the minds of many who notice them. Those associa-tions, which depend mainly on graphic works published during the same era, were unlikely to have been intended by the architect. They provide evidence in support of an associationist theory of aesthetic response that has gone out of fashion, and a salutary reminder that architectural historians must seek to see through the eyes of their period and not the projections of hindsight. Key Words: Alexander North, architecture, Federation styles, aesthetics, associationism.

\section{INTRODUCTION}

For an architectural historian, a particular interest is in why buildings look as they do, and that inevitably leads to questions of social history, geography, geology, economics, theology, aesthetics and even politics. Beyond questions of who did what, when and where, there is the mysterious, and frequently unanswerable, question of why? In approaching that, we can consider why, generations after the event and in a world of different presuppositions, we are likely to get it wrong.

In 2011 Foot and Playsted, the important Launceston printing and publishing firm, gave their graphic designers the task of producing a striking set of images of buildings in the city for their coming year's calendar. One of the results is a tenebrous drawing of the east end of Holy Trinity Church standing tall against a leafless tree and a lowering sky, the belfry and spire rendered in atmospheric detail, and a bird of ill omen flying away as if in fear.

Ravens have been considered harbingers of death, pestilence and ill fortune since ancient times. In the etchings of Charles Meryon, they appear in association with images of Gothic buildings, ever more intrusive as the artist's insanity advanced. His most familiar image, Le Stryge (1853), is of a devilish figure brooding over Paris from a tower of Notre Dame, with the birds circling the distant Tour Saint-Jacques and approaching to emerge beyond the picture-plane, menacing the viewer. In later etchings filled with foreboding, they wheel around the towers of the great cathedral and sweep in a flock to shadow the Left Bank, or fill the sky above the Seine. Since then, if not before, the association between the architectural Gothic and the bird of ill omen has become an iconographic cliché, part of the imagery of a popular fashion that has usurped the name of the architectural style. Its reappearance in contemporary Tasmania appears to have been evoked by the presence of a church surmounted by a most peculiar steeple, the most elaborate of a series designed by Alexander North, arguably the most important architect ever to practise in Tasmania. Why should a feature of his most admired building produce such a response in a later generation?

The work of Alexander North has yet to find the recognition it deserves. This is largely the result of geographical location, although his most celebrated building is the chapel of Trinity College within the University of Melbourne, and others appeared in South Australia, New Zealand and even in Fiji. Most of his work was in Tasmania where much of it can still be seen, but some of his most major projects did not achieve completion. Anyone in quest of North must rely greatly on the lifelong researches of the Melbourne historian, John Maidment, whose definitive publication on his hero has been long awaited, although he has been extraordinarily generous in sharing the findings from his work in progress (Maidment 1981, 1982, 1988). Maidment has stated that "North worked on designs for more than 200 buildings during his Australian career" (Maidment 2012, p. 504). North also figures in Caroline Miley's work on the Arts and Crafts Movement in Tasmania (Miley 1987), and the disappearing memories of those who knew him.

\section{ALEXANDER NORTH (1858-1945)}

North was born in 1858 in Huddersfield in the West Riding of Yorkshire, the son of a linen-draper. After leaving school, he was articled to an architect at Kendal in Westmoreland, and attended the School of Art there before moving to London where in 1876 he was working in the office of James Cubitt (1836-1912) and attending the Lambeth School of Art. As an articled draughtsman and a young architect, Alexander North travelled extensively on the Continent, and his later work was clearly influenced, whether by direct experience or through his publications, by the great French restorer and architectural theorist, Eugène-Emmanuel Viollet-le-Duc (1814-1879).

James Cubitt was not a member of the famous family of engineers and builders of the same name; he was the 
son of a Baptist minister from Norfolk who became a notable designer of Non-conformist chapels and wrote an influential treatise on Church Design for Congregations (Cubitt 1870). In that and other works he argued against the revival of mediæval compartmentation, the separation of nave, aisles and chancel, and the elongation and division of the congregational space. He complained that strong columns obstruct both sight and sound and slim columns are aesthetically unsatisfactory (Cubitt 1870, 1884, 1892).

While working for Cubitt, North prepared drawings for the Union Chapel in Compton Terrace, Islington. This building has a spacious octangular auditorium fronted by a bold square tower of red brick and contrasting stone, topped by an exiguous belfry and spire. This feature was noticed by Nikolaus Pevsner:

The external effect (and what a blustering High

Victorian effect) is the big red brick tower crowned by

an odd spirelet, breaking with the Georgian restraint

of Compton Terrace. (Pevsner 1952, p. 230)

The "odd spirelet" is an octangular belfry topped by a slated spire, mounted on the ridge of the gabled roof to the tower. The sloping timbers of the belfry are continuous with those of the spire, which is slightly flared at the bottom, a form that Alexander North was to use repeatedly in Tasmania, but with a wider flare, and arguably with a greater flair.

Cubitt's spacious preaching-houses clearly had their effect on the designs of the more liturgically-minded Alexander North; St John's and Holy Trinity in Launceston are both notable for the breadth of their congregational spaces, despite their traditional cruciform plans. An experience of the interiors of these two churches should be compared with those of Gothic Revival buildings based on the mediævalising principles of A.W.N. Pugin, like the Church of the Apostles in Launceston and the two cathedrals in Hobart.

In 1883 North was awarded a gold medal in Britain's National Competition for students of Schools of Art for original "cathedral drawings" (Launceston Examiner 1886). For some decades, British architects had been busily producing designs for Anglican cathedrals for the colonies, and North's competition entry was of this genre. The plan includes the wide congregational space enjoined by Cubitt, and resembles that eventually achieved at St John's in Launceston. In the same year, for reasons of health, North took ship for Australia, and arrived in Hobart late in the winter. In November he started work in the drawing office of the Department of Lands and Works, and his first major project was the Launceston Post Office, designed in what was described at the time as "Queen Anne" style, and opened in 1886, the year he left the government service.

While supervising the building of the Post Office, North recognised the opportunities to be found in Launceston at the time, for it was undergoing a minor boom, driven principally by mining, substantially capitalised, managed and equipped from the city: tin from Mount Bischoff and the North-East, smelted in the city, and gold from Beaconsfield, Lefroy and Mangana. The moneyed citizens of Hobart were well supplied with early colonial houses and later mansions designed by Henry Hunter and others, but in Launceston, there was a demand for houses to display the new wealth.

North's government appointment allowed a right of private practice, and he worked for a time in association with Leslie Corrie, who practised in Launceston before following his former master, Henry Hunter, to Brisbane in 1886. The first Gothic Revival design for the rebuilding of St John's Church, Launceston, was attributed to the partnership of Corrie and North, and Corrie was responsible for the 1884 design of the Catholic Church of the Holy Redeemer at Deloraine.

The work of North and his partners spanned the years when the city gained a remarkable heritage of buildings in "Federation Queen Anne" and related styles, designed by Thomas Searell, J. Martyn Haenke, Thomas Tandy the elder, Alfred E. Luttrell, A. Harold Masters, and others. Remaining city buildings from that era range in size from a once grand hotel to a former gentlemen's public lavatory, and even to a South African War memorial. North and his partners designed secular buildings in and near the city, but as a devout member of the Church of England, he was much in demand as an ecclesiastical architect, and he also designed for other denominations. He is best known locally for his two great unfinished Anglican churches, St John's and Holy Trinity, as well as two other parish churches within the city limits.

North was interested in botany, and in the promotion of Tasmanian timbers for export (North 1891, 1904) and he became a respected pillar of the local Arts and Crafts Movement (Miley 1987). His designs include traditional Gothic vegetable motifs, but his interest in native plants flowered in his Art Nouveau-influenced designs for capitals in the 1938 nave arcade of St John's, Launceston, exquisitely carved in wet concrete by Gordon Cumming (1894-1972).

North's partner in Launceston during many of the years before the Great War was the remarkable A. Harold Masters, a pioneer in the technology of electricity, radio telephony, X-ray photography and concrete construction (Masters 1900, Proverbs 1988, Neale 2012). Masters built his own house of "camerated concrete" as early as 1902, and was involved with North in the 1911 design of St Margaret's Hospital for the celebrated surgeon who became Sir John Ramsay, as well as other constructions in a material relatively new to architects, although longestablished in engineering and industrial use (Morris-Nunn 1989, Ratcliff \& Ratcliff 2005). Concrete was used to construct North's unique dome and pendentives over the crossing at St John's and the grain silos at Ritchie's Mill, both in 1911, and Masters's grandstand at Mowbray Racecourse in 1914 (Green 2006).

North's work for the Church of England in Tasmania also includes St Michael and All Angels at Bothwell and many lesser churches, but the present essay will be limited to those that carry the varied members of a family of steeples that appear strangely sinister to many viewers of those that remain today. 


\section{A MYSTERIOUS CHANGE OF CHARACTER}

Architectural history is dominated by notions of style, but the experience of buildings for most people is more likely to be coloured by less tangible qualities that are best described in terms of character. Buildings are described as humble or stately, imposing or unassuming, spectacular or unsightly, plain or ornate, handsome or elegant, cosy or frivolous, welcoming, or forbidding; some may be experienced as sinister, or in popular parlance, spooky.

In the last decade of the nineteenth century and the Edwardian decade, a peculiar change in aesthetic sensibility became widespread throughout the British Empire. It was not without parallels on the Continent and in the United States, but the particular British manifestations of it belong to our present subject. In the decorative arts, the advanced styles included what are now commonly identified with Art Nouveau, the Aesthetic Movement and the Arts and Crafts Movement. In architecture there was also Edwardian Baroque, Queen Anne Revival, Tudor Revival, a free style that embraced motifs from some or all of these, and an increasing North American influence; all of these are represented in Tasmania.

Although these styles show obvious differences, most of them share a quality that might be described in terms of emphasis and excess. These may be expressed in the sinuous lines of Art Nouveau that startled a world accustomed to simple geometry, Classical restraint or Gothic seriousness, or else the exaggerations of scale in Edwardian Baroque, or the complicated roof-forms, vivid colour contrasts, and multiplicity of surface materials characteristic of the revived "Tudor" and "Queen Anne". It was in the free conjunction of styles around the turn of the nineteenth century that the most emphatic departures occurred. Familiar examples include the exaggerated verticality in Charles Rennie Mackintosh's designs, more apparent in his furniture than his architecture, and the heavily simplified features and overhanging hoods above doorways in the work of Charles Francis Annesley Voysey.

Many of the leading English architects of the new generation that marched into the twentieth century had served their time under the great men of the later Gothic Revival, some of them veterans of a "battle of the styles" alleged to have been waged in the mid-Victorian period. It is a recurring tendency of youth to seek ideological purity, and judging from their mature works, many articled draftsmen towards the end of the nineteenth century appear to have expressed this in a search for a synthesis and a style that would be both "national" and in tune with the times. Whether or not that was ever achieved before the field was overtaken by "international" modernism is still a subject of some interest (Crook 1987).

These articled draughtsmen had become accustomed to the vertical emphasis of Gothic, and this survived their youthful rebellion, but the spirit of the age was, for reasons that remain mysterious, against carrying the eye of the viewer into the sky by means of pinnacles, and from the ghost of the Classical tradition came horizontal features to put a stop to that (pl. 1). Some have retrospectively

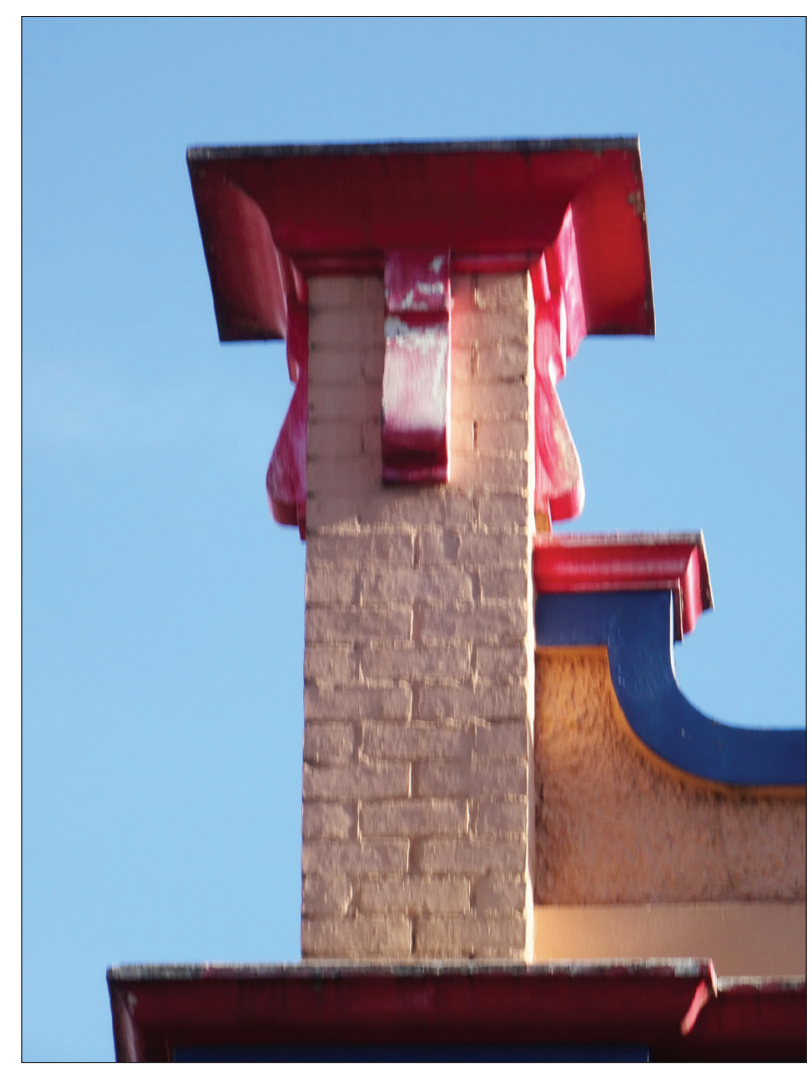

PLATE 1 - A. Harold Masters: mortar-board finial, Barratt's Music Store, Launceston.

seen this as symbolising the ending of the last great "age of faith", or a premonition of the disasters to come in the twentieth century; buildings could no longer point to heaven, but they might be needed to hold up the sky. In the design of all buildings above the ground, there is a tension between the vertical and the horizontal, but one of the recurring characteristics of Edwardian architecture in all its styles is a particularly emphatic expression of that tension. Victorian building was characteristically heavy on the ground, but usually aspired towards the heavens. Suddenly, in the last decade of the century, the most innovative architects began to deny that.

Some manifestations of this are frequent and familiar in Tasmanian buildings of the period. For several generations, internal architraves had most commonly consisted of a series of mouldings around the opening, usually continuous and mitred at the corners. Suddenly, the mouldings became simpler or disappeared entirely, and at the top was placed a horizontal cornice like a narrow shelf. Furniture designs reflected the change even more emphatically; finials on vertical timbers either disappeared or gave place to flattopped elements. When features like these appear on a larger scale on the outside of buildings, they remind us of Lewis Carroll's parodic "tea-tray in the sky", particularly when they are finials. The little domestic towers, the chimney-tops, had long been given mouldings near the top, but these suddenly became thinner and wider in the hands of some designers, and the Tasmanian architectural practice that is examined in this essay took them to an 
ultimate extreme, a particularly emphatic expression of the apparent shift in aesthetic sensibility (pl. 2).

The Australian colonies that became states of the Commonwealth in 1901 also had architects in search of a style that might express the spirit of the age, and in the writings of a few (but not conspicuously in their buildings) there were expressions of a wish to develop a national style. It has also been argued that the national aspirations of the majority were as much inclined towards Imperial solidarity as to Australian patriotism, and even to an Anglo-Saxon racial sentiment (Willis \& Goad 2008). Their houses, like the bungalows of British India, were devised to shelter an essentially British way of life, but with external appearance dictated chiefly by economics and climate, and therefore a strong contribution from the colonial traditions of the large exposed roof and the surrounding verandah.

This is not the place to argue for or against the stylistic term "Federation" that rapidly prevailed in Australia after it was first proposed by the art and architectural historians Bernard Smith and David Saunders, and is now so beloved of real estate agents and developers (Smith 1969, Saunders 1969). It has been argued that the styles, at least in their domestic manifestations, are characteristically Australian, and there has been attributed to them a nationalistic motivation, a projection that relies chiefly on the coincidence of the years of their development with those of the political movements that led to Federation (O’Neil 2000). A national motive can be discerned in the appearance of terracotta kangaroos in place of French dragons as finials upon Marseilles-tiled

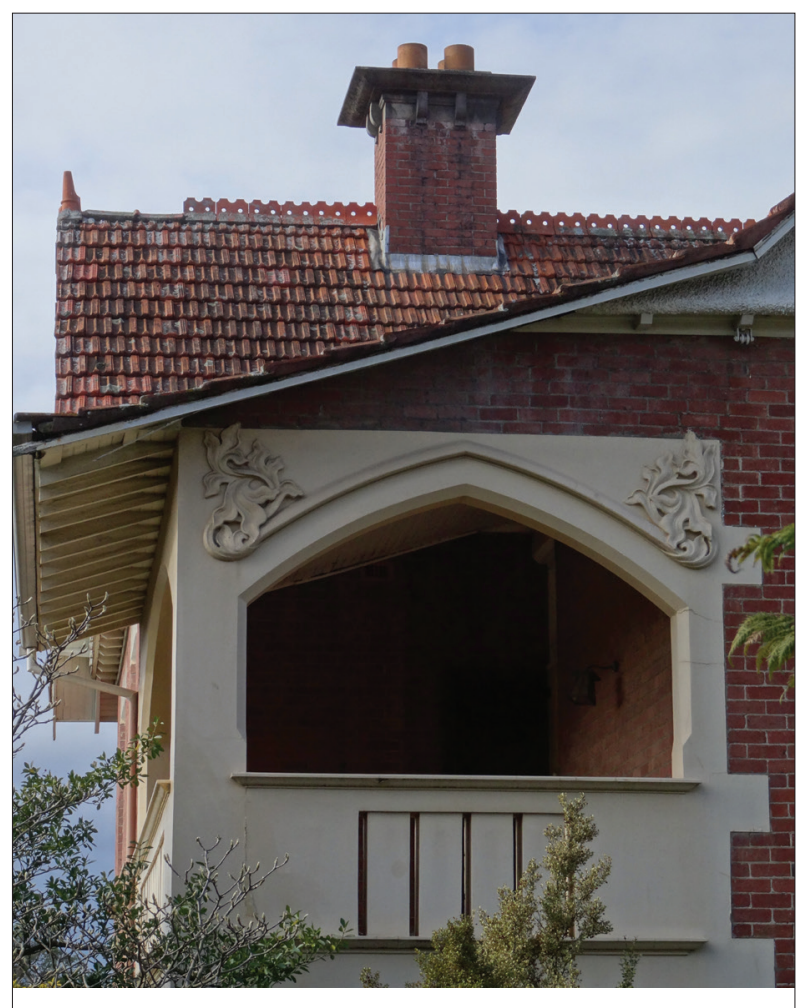

PLATE 2 -A. Harold Masters \& Alexander North: house in Elphin Road, Newstead. gables and the representation of native fauna and flora in lead-lighted windows, but in little else. Most of the architects involved were British-trained if not Britishborn, and the external appearance of their houses was a characteristic response to antipodean requirements and conditions, enclosing interiors essentially identical with their English contemporaries. Eucalyptus hardwood was fumed with ammonia to darken it, and given the trade name of "Tasmanian oak", a persisting term that smacks more of "cultural cringe" than of nascent nationalism.

The "tea-trays in the sky" had made their first prominent appearance indoors, in miniature, and in London. In 1884 Arthur Heygate Macmurdo, one of the founders of the Century Guild, an important association in the development of the Arts and Crafts Movement, designed an exhibition display consisting of a furnished room with two walls replaced by thin colonnades to allow the interior to be viewed (Pevsner 1936, 1968) (pl. 3). The square posts were given excessively wide capitals and supported a broad shallow cornice, and above that was a series of panels separated by slim piers that ended in most peculiar finials: flat square "trays" or "mortar-boards" that stopped the rise of the gaze with a sudden jerk. The room was exhibited again in Liverpool in 1886, and a magazine illustration of its appearance there started a fashion that spread even to these far Antipodes.

The motif was applied by North's now celebrated contemporary in England, C.F.A. Voysey (1857-1841), and in the first decade of the new century his designs for furniture and buildings were illustrated in periodicals such as The Studio, read in the colonies by people who wanted the latest from Europe. Downmarket versions appeared in the catalogues of such firms as Foy and Gibsons in Melbourne and Coogans in Tasmania (Coogan 1913, Foy 1923). The vertical members of chairs, bedsteads and chimney-pieces and any other items that could be made to project above the horizontal were capped with little square finials.

The much larger versions that appeared atop the piers and parapets of buildings in Launceston emerged particularly from the office of Alexander North and Harold Masters. North does not seem to have been content to stop at the horizontal feature, and some bizarre embellishments are attributable to him. In 1907 McKay, Sampson and McKinlay's department store in Brisbane Street was destroyed by fire, and the front of North's very up-to-date replacement did not finally culminate in Macmurdo finials; those at the ends support large balls on Art Nouveau legs (pl. 4). Even more outrageous finials topped the belated Art Nouveau verandah added to the plain Georgian Berriedale Inn at Westbury, across the road from North's completion of the tower of Henry Hunter's Holy Trinity Catholic Church. North was no conserver of early colonial architecture; three of his churches involve alterations and additions to existing buildings in ways that entirely change their character, and that was also the case at Westbury. Plainer but more emphatic examples of the mortar-board finial were applied to buildings that can be attributed to his partner, Harold Masters. 
PLATE 3 - Arthur Heygate Mackmurdo: Century Guild Stand, Liverpool International Exhibition 1886.

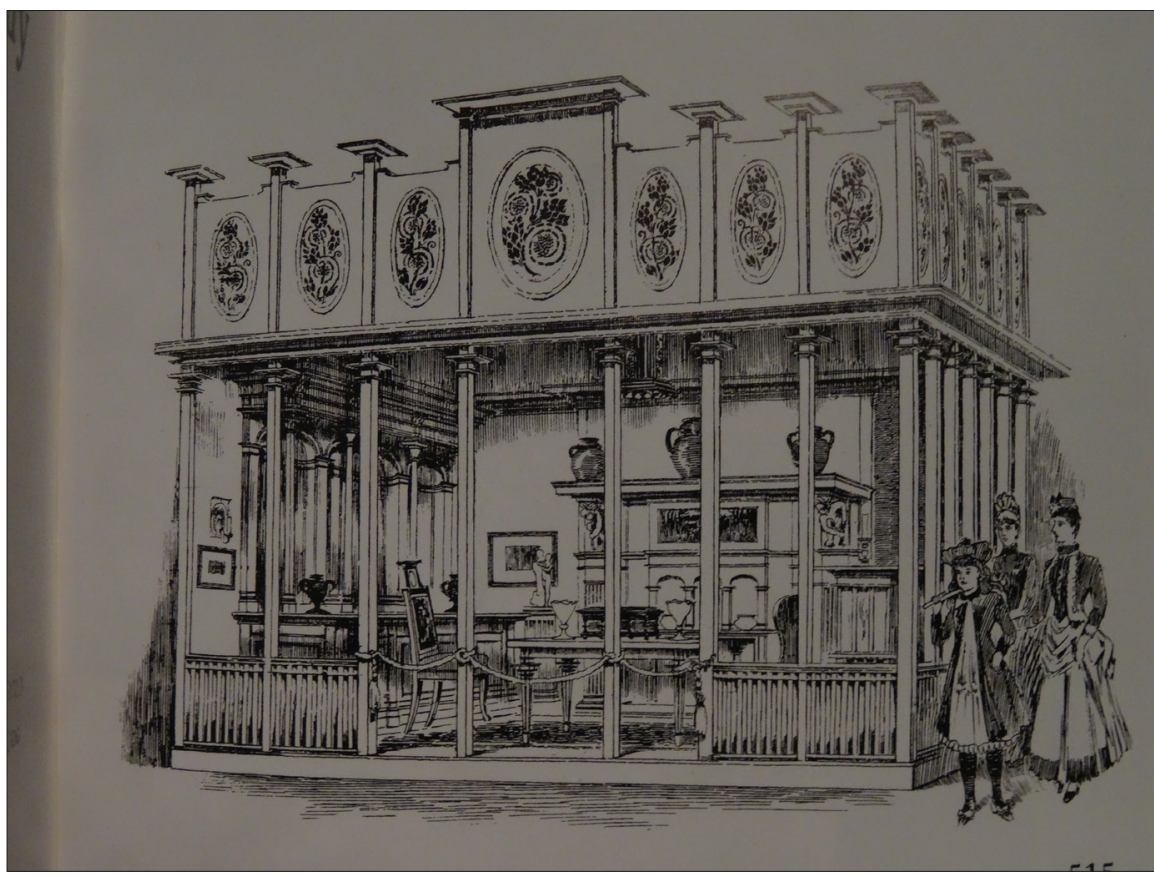

At No. 79 Elphin Road, Launceston, is a house that has some of the red brick and Gothic of North, and some of the freestyle concrete of Masters. Its chimneys carry cornices even more emphatic than Barratt's finials. In about 1910, North or one of his associates designed the Newstead Hotel, a replacement for one of the few suburban hostelries in the city. It is still a handsome

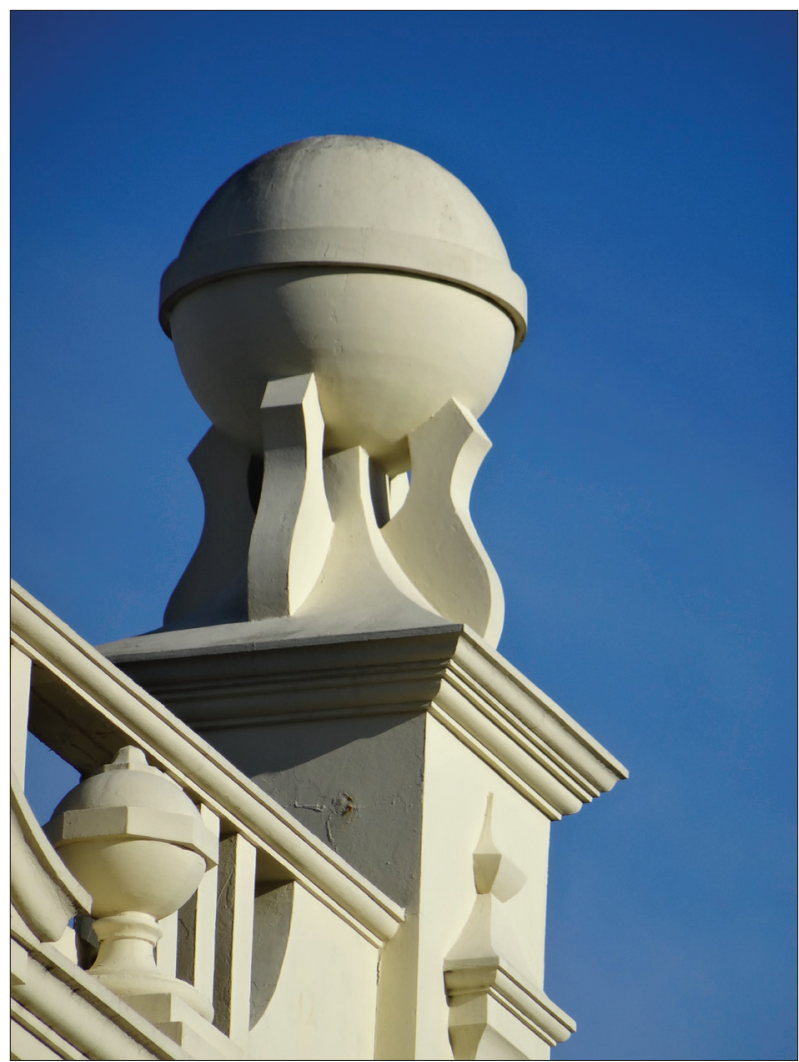

PLATE 4 - Alexander North: orb finial, former McKinlay store, Launceston. building, despite the commercial mutilations that appear to be inevitable to its trade. High above the roof there can still be seen what may be in proportion the widest and shallowest cornices ever to appear on an Edwardian chimney-stack (pl. 5). They are about two and a quarter times as wide as the supporting shaft, and were probably achievable only through Harold Masters' mastery of

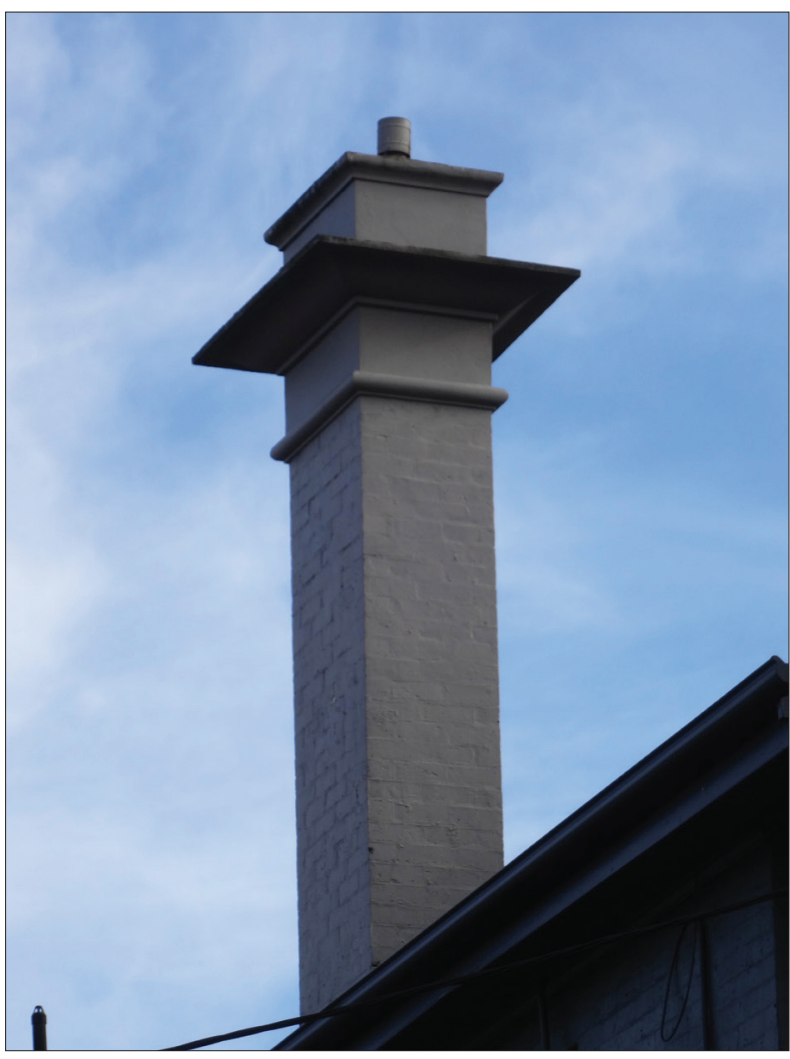

PLATE 5. - A. Harold Masters: chimney-stack, Newstead Hotel, Launceston. 
concrete. The cornices are just that extra bit wider and slimmer than any of the others in the city, if not in all of Australasia. They would not have been easy to make, and the exaggeration was clearly deliberate, a minor apotheosis of the prevailing fashion.

The derivatives of Macmurdo's "tea-trays" might arrest the rise of the gaze above commercial façades or domestic chimneys, but Alexander North was not one to stop the reach of his churches towards Heaven. He did, however, express the horizontal spirit of his age even in his steeples, and the results of that are now to be examined more closely.

\section{OF STEEPLES AND SPIRES, AND CHANGES OF PITCH}

It is necessary here to introduce a note on nomenclature, to avoid confusion. Steeples and spires are not quite the same thing. The term "steeple" is mainly held to imply a church tower, whether crowned with a spire or not. Early English and American Quakers and some other non-conformists called places of worship "steeple-houses", for a church was for them a body of believers and not a building, and in the sixteenth century, the term "spire-steeple" was used to distinguish a tower topped with a spire.

Spires on churches are an invention of the middle ages, a deliberately spectacular exaggeration of the conical or pyramidal roof required for a tower. We readily associate their tall pointed forms with Gothic, but they originated near the time when the later builders of the Romanesque had just begun to recognise the advantages of the pointed arch, both in structure and in the architectural expression of the meaning of a building. One of the earliest that can be closely dated is the still incomparable one on the south tower of the cathedral at Chartres, completed in 1165, just eleven years after the completion of Abbé Suger's innovation at St Denis that is considered to be the first major essay in Gothic.

In the middle ages, spires were more often an aspiration than an achievement; even the cathedral at Chartres was intended to have nine and has but two, and the cathedrals of Paris and Rheims had none until Viollet-le-Duc added his ornate fleche above the crossing in Paris in the nineteenth century. Melbourne has two cathedrals each with three spires, a phenomenon unknown in any city in Europe! Smaller mediæval churches were generally provided with a tower, not merely to house a bell, but also in some cases to accommodate the priest. These were topped with spires whenever they could be afforded. England and Ireland have many spires; in Scotland they appear also on secular buildings, and they are entirely familiar in these antipodes, but nowhere are they more prevalent than in France.

The visual transition from a square tower to a pointed spire can be accomplished in five ways. The simplest, generally found in Germany, is the steepened pyramid; the others require some architectural device to make the transition visually satisfactory. The belfry stage of the tower could be made octangular, with sloped set-offs at the corners, as in Henry Hunter's towers at All Saints in
South Hobart and St John's at Ross, and in William Henry Clayton's work at St Andrew's in Launceston and St Mark's at Deloraine. Subordinate pinnacles could be placed on the corners of the tower; this can be seen in excelsis on Salisbury Cathedral in England, where little spires gather at the foot of their mother. In simpler form, it explains the pinnacles on the now spireless tower of the church at Port Arthur. Another expedient is the broach spire, where the corners are given little pyramid-like structures that lean into four facets of the octangular spire. These can be seen in Hubert Springford East's splendid addition to St Mary's Church at Hagley, made in 1932. North chose the fourth expedient, the splay-foot spire, in which the steeper part emerges from a less precipitous roof that overrides the walls of the tower. The architectural advantage of this is that the steeper section can have any number of sides, four, six, eight, or even more, unlike the other forms, limited to four or eight. The economic advantage is that a spectacular result can be achieved with relatively cheap materials.

Between 1889 and 1901, a belfry and steeple were built to straddle the ridge over the crossing of the new Holy Trinity Church in Launceston (pl. 6). The building, North's unfinished masterpiece, combines red brick and mustard-coloured sandstone in a fin-de-siecle Gothic that is in debt to many sources, yet highly original. It was intended to have an uninterrupted roof extending over nave, crossing and chancel, with lower transepts enlivened with semicircular appendages, a clergy vestry with a conical

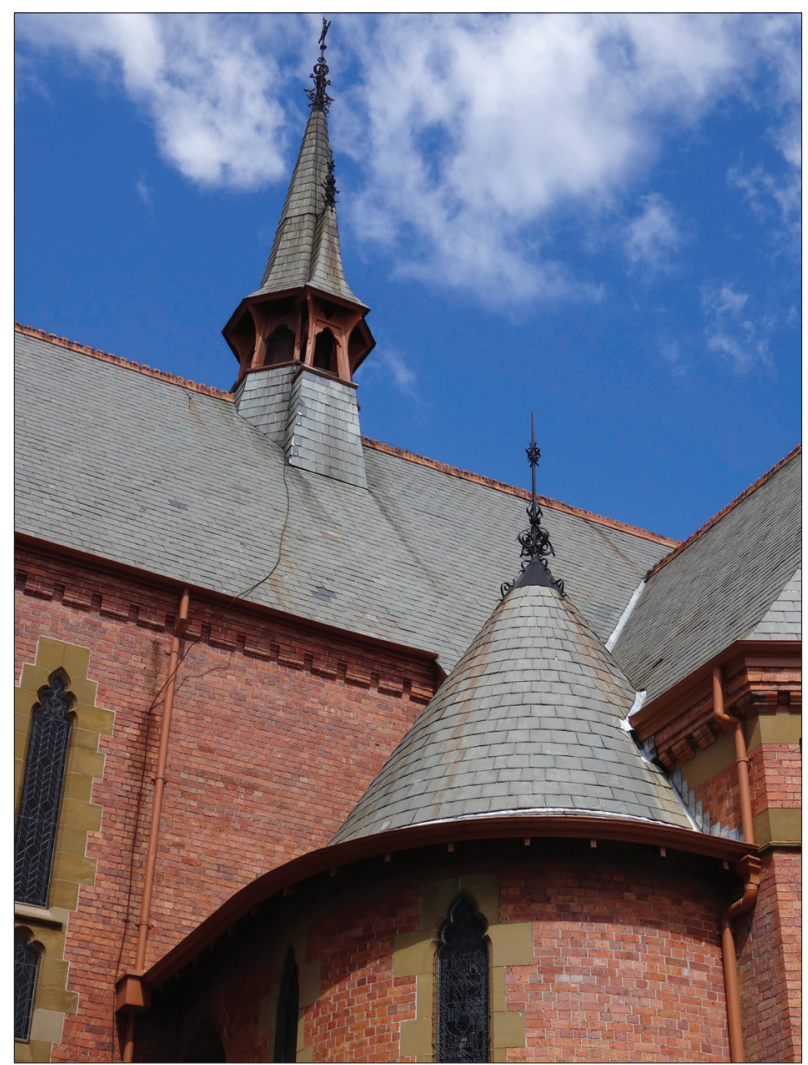

Plate 6. - Alexander North: Holy Trinity, Launceston, belfry, fleche and north transept chapel. 
roof on the south side and an apsidal chapel to the east of the north transept. The exterior of the latter makes North's debt to the great French architect and restorer, EugèneEmmanuel Viollet-le-Duc, very clear. The Dictionnaire raisonné de l'architecture française du XIe au XVIe siècle was published from 1858 and completed in 1875, and the illustrations if not the text had a profound influence on the last phase of the Gothic Revival in England, the time when Alexander North was articled. The conical slate roof on the chapel at Holy Trinity shows the change of pitch that Viollet-le-Duc used to such striking effect on such works as the bastions at Carcassonne or the towers of the Chateau de Pierrefonds in Picardie - powerful reinstatements rather than restorations (pl. 7).

The shallowing of the roof pitch just above the eaves is characteristic of parts of Europe with a high snowfall, and for this and unrelated reasons was a regional characteristic that became widespread in France during the nineteenth century, so much so that it imparts a Gallic air to almost any building it is applied to (pl. 8). Some of the lithographers making prints after the drawings of the artists attached to the French expeditions that visited Van Diemen's Land in the early decades of settlement show our colonial cottages with roofs of similar form, which they did not generally have. They make it possible to imagine what the settlement at Sullivans Cove might have looked like if the French had settled there first.

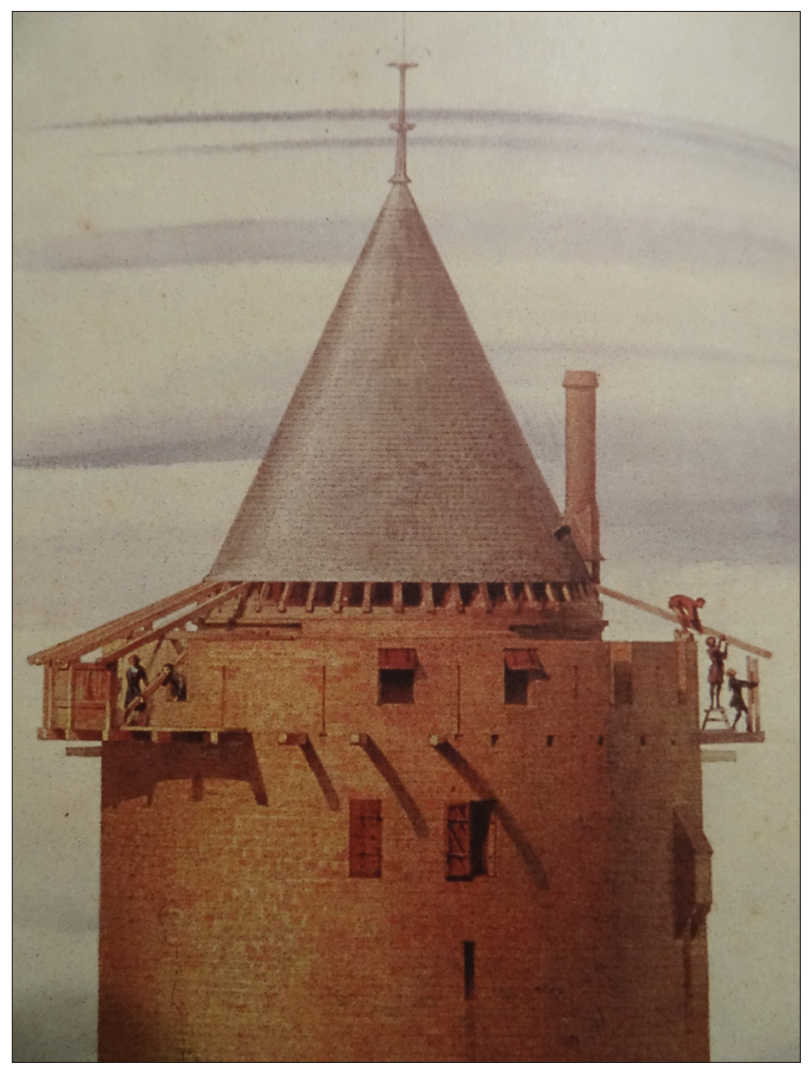

Plate 7. - Eugène-Emmanuel Viollet-le-Duc: detail of watercolour of scheme for restoration of Tour de la Vade, Carcassonne, 1853.
The form is made possible by the use of a little subsidiary rafter, in English described as a sprocket and in French a coyau (Lavenu \& Mataouchek 1999). Viollet-le-Duc used coyaux to give his conical roofs a Gallic frisson with varying degrees of emphasis, some with narrow eaves and a few almost as wide as Alexander North's. The form is thought to have two independent origins: in regions subject to frequent snowfall, it was probably intended to throw snow sliding from a steep roof clear of the walls; in Languedoc, it may have originated in structure to support the eaves of a thatched roof, the shape being hidden under a thick layer of thatch until revealed by its replacement with a covering of tiles or slates (Donald 1995). Its structural advantage in a steeple is that the principal timbers can rest directly on the walls.

The flare above the eaves can be applied to a pitched roof of any form, but when it is applied to a spire, it becomes an emphatic feature. Alexander North added further emphasis, creating a strong visual feature as well as a way of keeping the water out of the walls, but the exaggeration results in a complete change of character. In his ridge-mounted spires, with the main structural timbers appearing below them as the leaning pillars of the belfry, he used the flare to visually separate the one from the other, another expression by North of that horizontal emphasis characteristic of an era more imperial than pious.

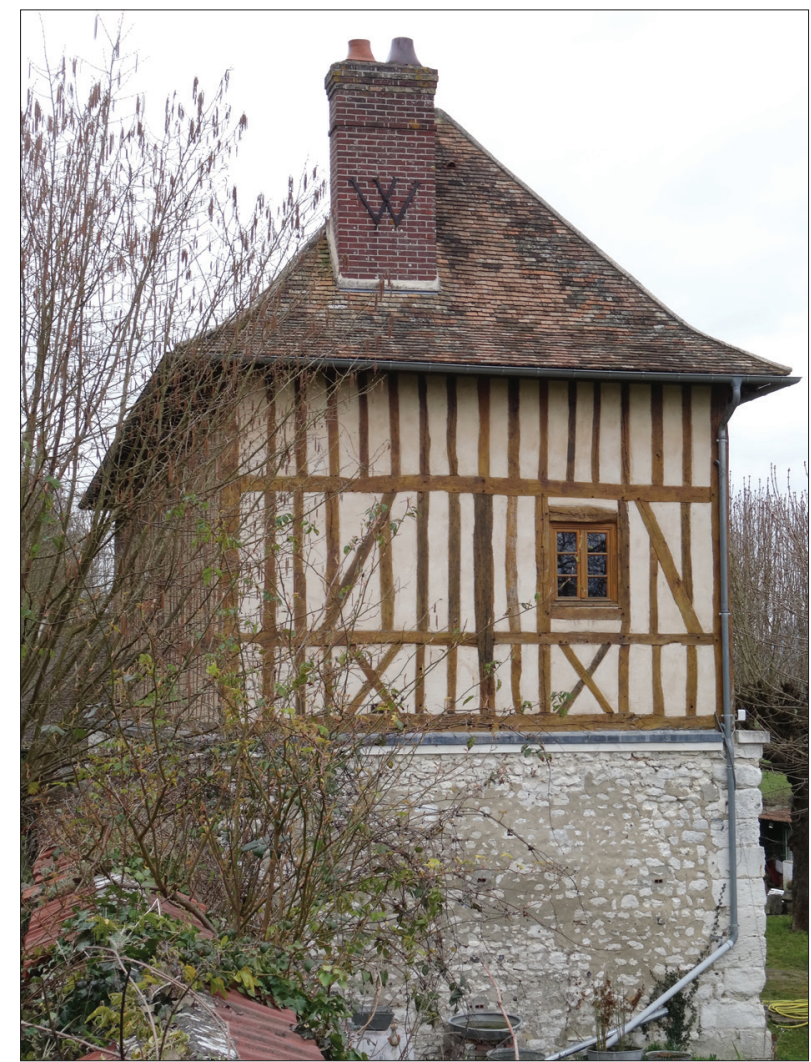

Plate 8 - House at Vernonnet, Normandy. The coyeau form of the roof probably reflects replacement of thatch with tiles. 


\section{SINISTER STEEPLES}

North applied the splay-foot form in a number of different ways, some much taller than they are wide, some wider than they are tall. The spire may be square, hexangular, octangular or more complex in plan, and it may be clad with slates or sheet metal. In their emphatic form they have no significant precedent in English church-building, even during the late nineteenth century, but a little more in France.

The earliest of Alexander North's sinister Anglican steeples in Tasmania is at Nile, south of Evandale. In 1850 a plain red brick schoolroom had been built in the hamlet, then known as Lymington. In the following year it was dedicated for use as a church, and in 1893 was made to look like one by Alexander North who altered the side windows and added a chancel, a vestry, a tower and buttresses, before the building was consecrated as St Peter's Church, Nile (pl. 9). The additions were in Alexander North's favoured red Sandhill brickwork, with hood-mouldings of moulded special bricks and foliated terracotta castings at the drips. The sloping buttresses of the tower create a false perspective that makes it appear taller than it is, and it is crowned with a hexangular spire emerging from a wide pyramidal roof with a slope of about 30 degrees and overhanging eaves. The spire and roof are clad with rugged grey slate like the scales of a Trachysaurus lizard, varied with a band of slates with pointed tails. The light colour and attractive irregularity of the slates makes

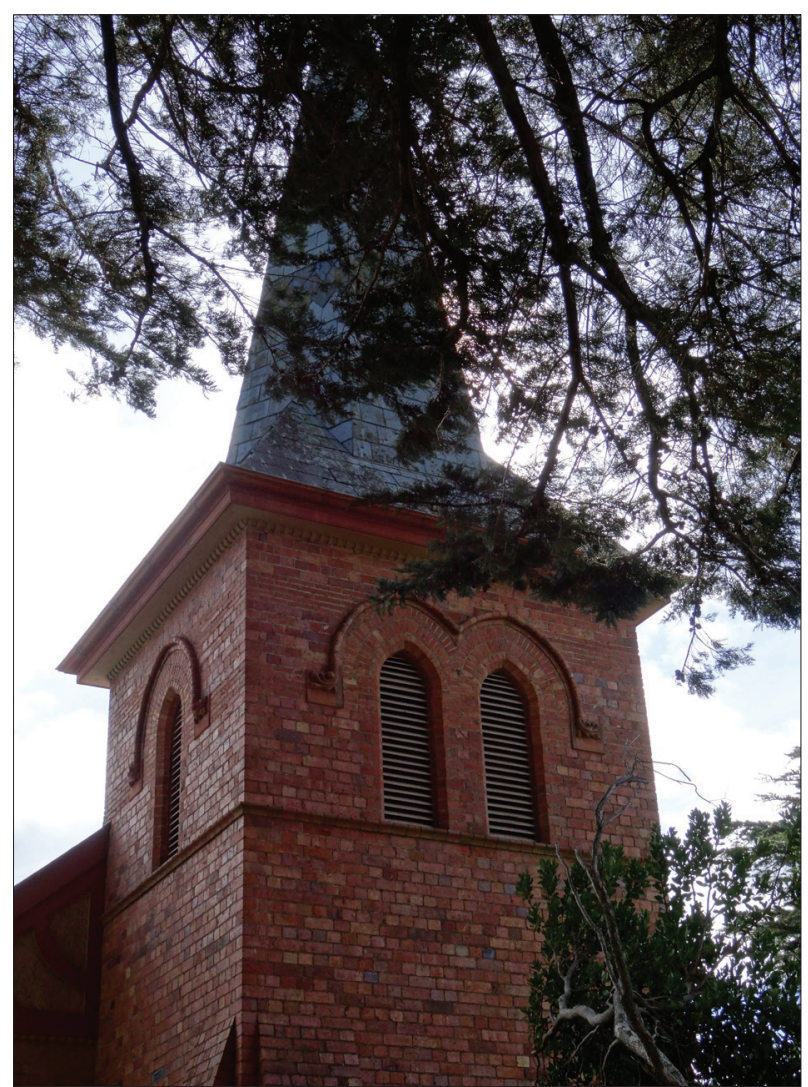

Plate 9 - St Peter's, Nile, brick tower and slate-covered spire. it highly likely that they are of Tasmanian origin, probably from the newly-opened quarries to the east of the Tamar Valley at Bangor or Turquoise Bluff. Seen from the front, the paired pointed openings of the belfry stare down at the viewer from under hood mouldings, greatly increasing the impression created by the reptilian hat.

The much more elaborate fleche at Holy Trinity, Launceston, that gave rise to this essay was next in order of construction. The building was designed by 1898 , and the spire was in place by the time of its consecration in 1902 (Branagan 1989, Gill 2010). The spire is clad with slates, and is mounted on the ridge of the roof above the centre of the crossing. It has subsidiary wings on both sides with roofs that descend to a lower level than that of the spire. The roofs are flared at the bottom and shelter an open belfry whose sloping timbers are continuous with those supporting the spire and the wings. Cusped spandrels in the belfry and wrought iron finials provide the elaboration necessary to harmonise with a complex form.

In 1903 a small weatherboarded church was built for the railway village of Parattah in the Eastern Midlands. North designed St George's with a louvred belfry and small spire, square in plan and mounted diagonally on the ridge of the roof, but this was elaborated into the hexangular structure that stands today, the metal-clad spire being flared at the bottom to throw water clear of the belfry, and to provide a visual separation. The posts of the belfry continue upwards as supports of the spire.

North must have become exceedingly familiar with the railway journey between Launceston and Hobart, for in 1907 he was supervising the rebuilding of the chancel of St David's Cathedral in Hobart; the previous work carried out under the supervision of George Fagg in succession to Henry Hunter had had to be taken down because of foundation problems. He is thought to have visited England and consulted G.F. Bodley, the designer of the cathedral, but it is not certain that they met as Bodley died later in the same year (Boyce 2012). North's other major Anglican project in Hobart was the cloistered wing added to the old Hutchins School in Macquarie Street, opened in 1914.

Edward Dumaresq built a schoolroom of rubble bluestone and brick on a hilltop on his property at Illawarra on the edge of the Norfolk Plains in 1841-1842. As at Nile, the schoolroom doubled as a chapel-of-ease, dedicated as Christ Church, like the mother church at Longford, and a chancel was added in 1888. In 1905 Alexander North designed a new chancel and transepts, an Arts-and-Crafts Gothic porch, and a squat tower over the crossing (pl. 10). This is crowned with the broadest of his characteristic spires, clad with sheet metal. The splay foot is square in plan, with a gentle catenary curve, its broad eaves supported by curved corner brackets. The perfectly proportioned peak is octangular. A plain rural building with an excellent site has become a cruciform landmark that seems entirely at home on its hilltop, for North has avoided the spectacular and harmonised his steeple with the breadth of the tower the shape of the hill and the low pitch of the old schoolhouse roof. 
North's next commission was for a spacious weatherboarded Holy Trinity Church of England at Beaconsfield; its predecessor had become too small for the busy gold town by 1907 . North responded to its unremarkable corner site by placing a square tower at the corner. The boom went bust, and the belfry and spire were not completed until 1925; the latter, clad with sheet metal, followed on a smaller scale the form he used at Illawarra, except that the steep part is four-sided. Although not the first to be executed, this was the first of North's designs for a square tower topped by a louvred belfry of similar breadth and a metal-clad spire that looks as broad as it is high.

The finest of his metal-clad spires was raised in another gold-mining town, Mangana near Fingal, in 1910 (Andrews 2001) (pl. 11). This outstanding little church for a Catholic congregation was built of concrete, the surfaces not rendered but displaying evidence of excellent form-work, and green and brown glazed earthenware tiles are inset flush with the surface to stand for architectural decoration. The entrance porch is the lowest stage of the tower. Our Lady of the Sacred Heart would be a gem in any landscape; it is durable, practical, innovative, quirky, and beautiful, and as always, the metal-clad spire is perfectly harmonised with the hilly surroundings. The grey concrete is now painted white, but without detriment to the overall effect of a remarkable building.

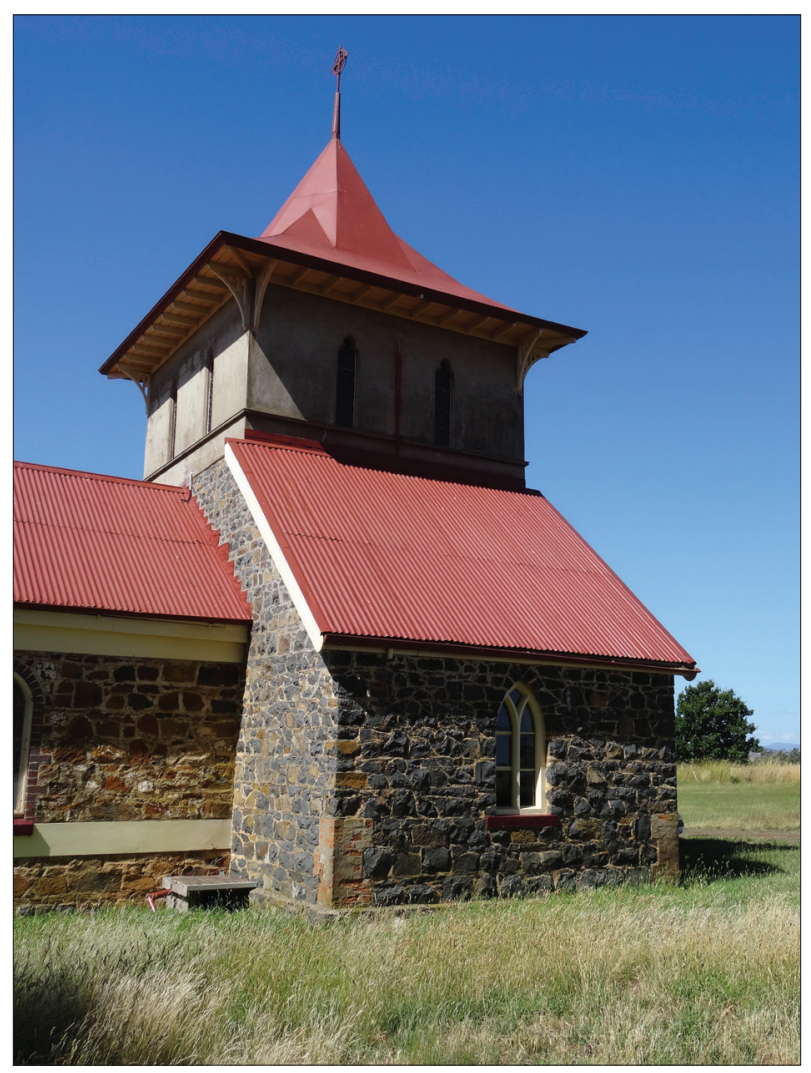

Plate 10 - Christ Church, Illawarra (Tasmania), Alexander North's transept and tower, the original schoolroom at left.
A more economical version was built at Lachlan near New Norfolk in 1911, to replace a chapel-schoolroom destroyed by fire (Henslowe 1978). The former St George's is of timber clad with roughcast render, and the tower and belfry have been given sloping sides to create an illusion of solidity and height. The tower contained the vestry, and above the open belfry, a square witch's hat covered with sheet metal extends over wide eaves.

A weatherboarded church was built at Pipers River in 1912 (Henslowe 1978) (pl. 12). For St Alban's, North returned to the idea of a ridge-mounted belfry and spire as at Parattah, but he rotated the hexagon so that two angles of it rested on the ridge, and the apparent belfry is without a bell and enclosed with small weatherboards; it is purely symbolic. The sharp metal-clad spire is hexangular, its timbers continuous with those of the dumb belfry. As at Parattah, the flared skirt of the spire makes a clear separation between it and the belfry.

For his home parish of Exeter, North designed in 1916 a plain but elegantly proportioned and detailed church to be built of local brick, with a square tower topped again with a louvred belfry and broad spire (Henslowe 1978) (pl. 13). As at Lachlan, the tower of All Saints contains the vestry, so it is placed near the holy end, and here that is towards the street, for this church is approximately oriented, altar towards the east, so the entrance is at the end distant from the street. The hand-moulded bricks

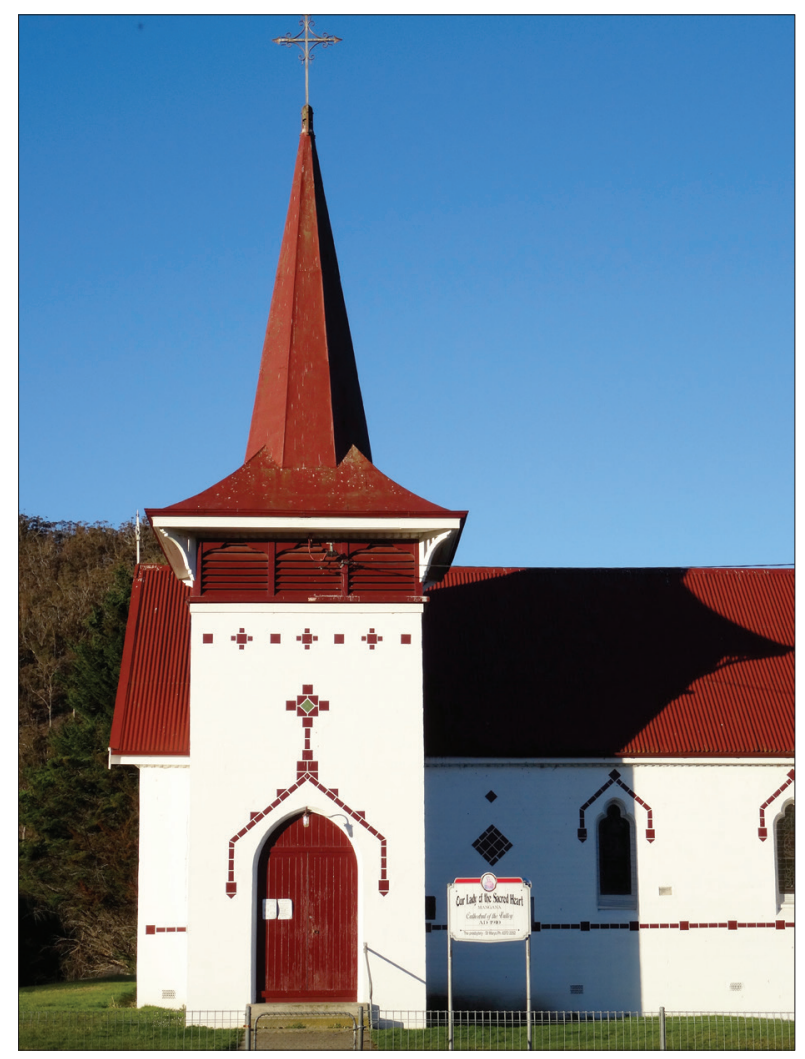

Plate 11 - Our Lady of the Sacred Heart, Mangana, a concrete church for a gold-mining town, decorated with inset glazed tiles. 


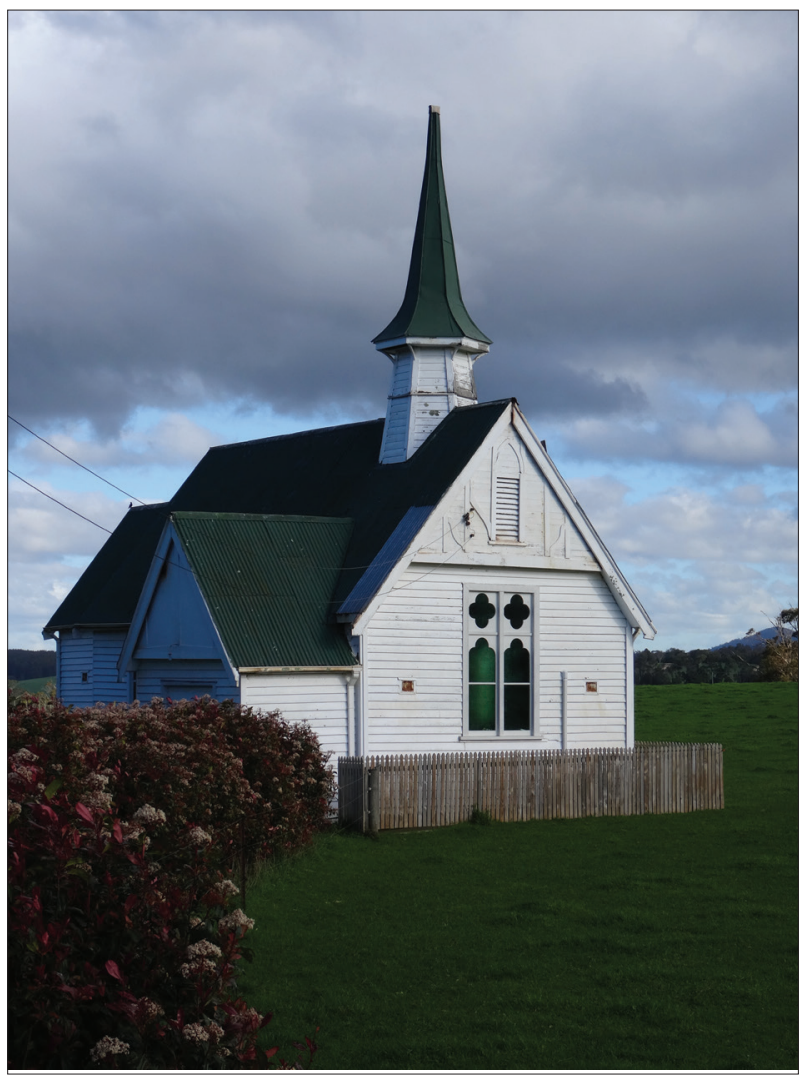

Plate 12 - St Alban, Pipers River, a characteristic wooden country church by Alexander North; in this case the spire surmounts a false belfry.

are of an unusual colour, made at James Edwards's Loira brickworks, the remnant of a dynasty that supplied bricks for Beaconsfield in the boom years (Nyman 1988). The building stands as a monument to North's paper on The truthful treatment of brickwork (North 1892), here executed by local builders. Alexander North lived, and died in this parish, so we can be sure he exercised his most careful supervision on the building of this little church, making it both economical and elegant.

The Methodists also built a church at Exeter in 1916 (Stanshall et al. 1976). It is a wooden building, but much less routine than many that had been built in the three decades before the Great War, for it is clearly the work of Alexander North, and if its generous and economically decorative windows did not make this clear, it is topped with the smallest of his ridge-mounted spires and belfries, this time square in plan and clad with sheet metal impressed with a fish-scale pattern.

It would appear that North had designed a church for the Methodists before, as early as 1891 (Stanshall 1976) (pl. 14). It was paid for by the local mining magnate, William Hart, and gifted to the church; and it still stands at Bryan Street, Invermay, confronting the viewer from Albion Street with the weirdest spire of all, square in plan and mounted diagonally on a small false belfry with squashed elliptical openings. The church has become a Tibetan Buddhist centre, and the spire must appear oddly familiar to those accustomed to some roof-forms of Central Asia.

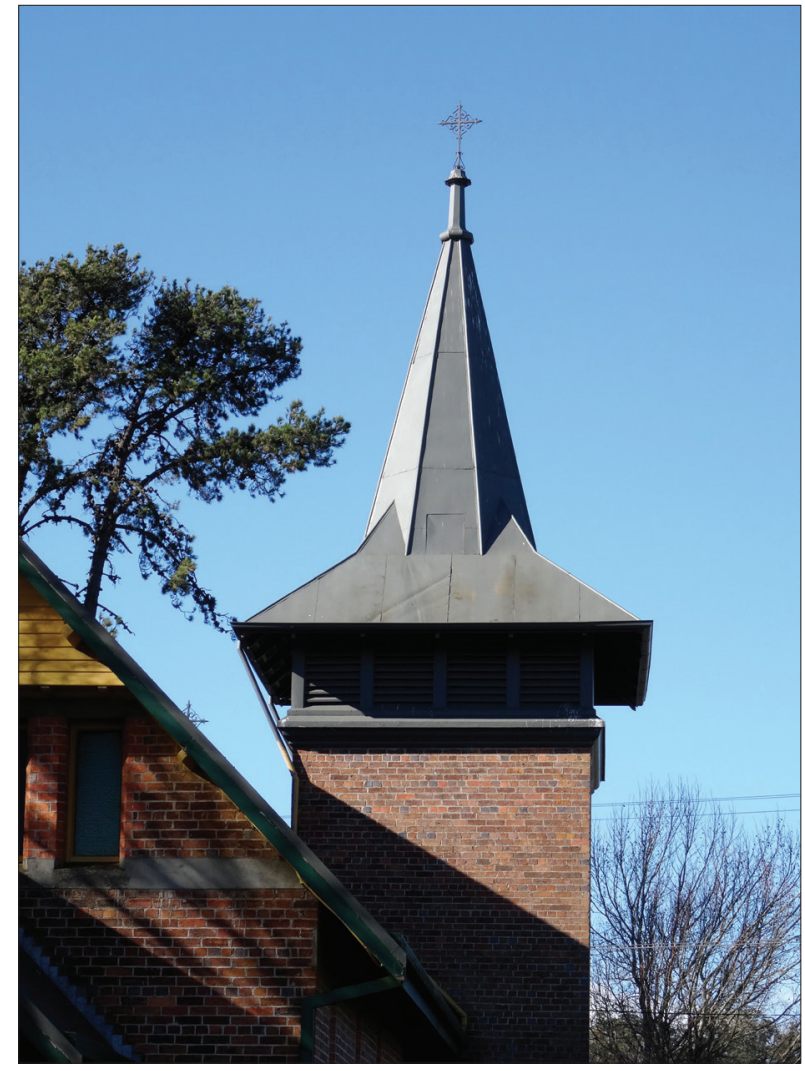

Plate 13 - All Saints, Exeter, Alexander North's own parish church.

The last, lowest, widest and cheapest of North's spires topped the Church of the Holy Family at Inveresk, built in 1930. It was a weatherboarded mission church of faintly cruciform shape with a tower clad with fibro-cement sheeting with cover strips painted to give a half-timbered effect. Despite its materials, its distinctive profile provided an impressive landmark in a flat industrial suburb. It did not overwhelm its humble neighbourhood, but greatly enhanced it until it was burnt down in 1971; its replacement provides little to inspire the viewer.

In his paper on Rural Churches (North 1905 n.p.), North argued strongly that small churches should not attempt to imitate great ones, that they should be true to their material, and when this was timber, it should not be in "imitation of pointed stone construction". "[A] pointed arch carried out in timber is a miserable sham", he roared, a manifestation of "that abominable debasement of construction known as 'carpenters' Gothic"'. It would seem that North's metal-clad steeples were another expression of that philosophy. The visible supporting timbers or the louvred belfry below the splay clearly show that the intention is not to imitate masonry or brickwork; the steeples are made of what they are made of. Honest, practical, economical, but what of their form? 


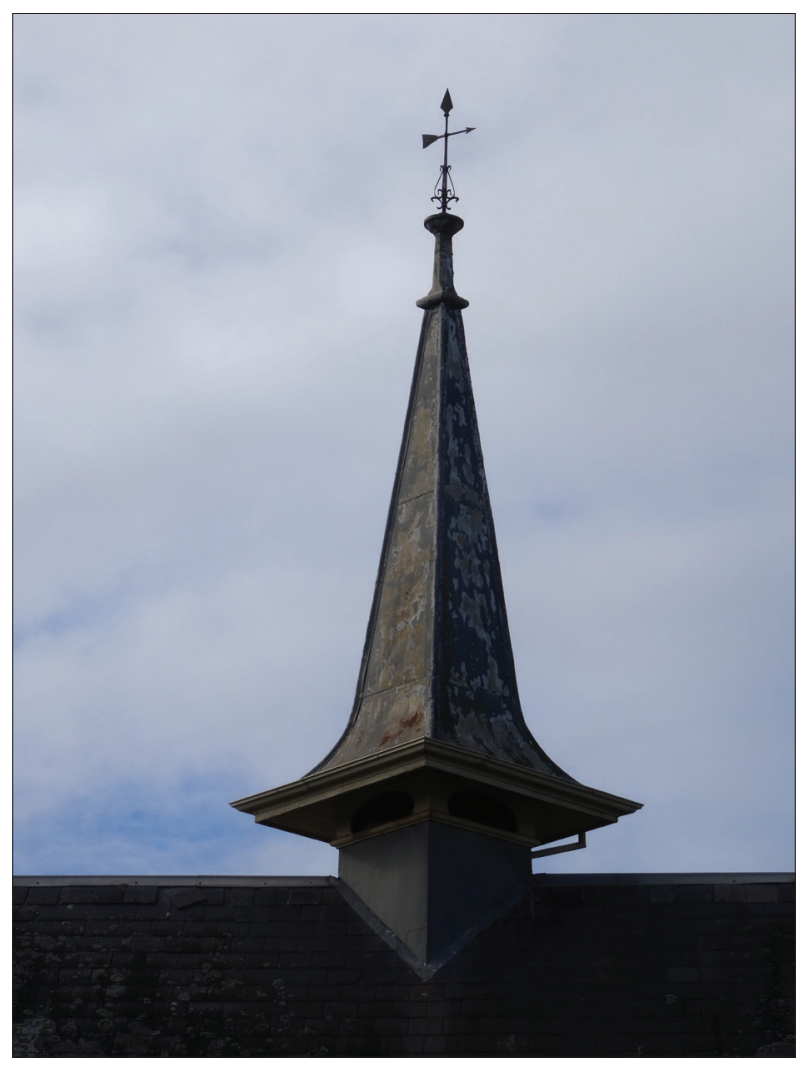

Plate 14 - Former Invermay Methodist Church, North's most sinister spire.

\section{WHY SINISTER?}

The fashionably "Gothic" perception of Alexander North's steeples raises a number of questions, some of them of historical interest. Is the perception entirely a projection of the viewer, conditioned by association of familiar images of story-book witches, or is it somehow inherent in the design? If it is inherent, was the effect in any way intended by North, or is it an incidental result of his chosen proportions? And if this last, why the repeated use of such proportions? Was the exaggerated horizontality and the varied verticality merely North's response to the hilly terrain of Tasmania?

The sinister appearance of Alexander North's steeples to many who view them today is largely attributable to association; many liken them to witches' hats. Several generations of children have been accustomed to witches in story-books wearing hats with a brim and a crown that comes to a sharp peak like a steeple, but that convention appears to date from the end of the nineteenth century and was probably not clearly established in the minds of former children at the time when the steeples were designed. The association appears to be peculiar to Western Europe and North America, and is an essential of the fancy dress of Hallowe'en as currently celebrated in the United States and its imitators. From the vantage point of adult life, the witches and their hats appear innocuous and even comic, but our response to the silhouette of a North steeple owes more to the frisson of fear that accompanied our earliest encounters with them.

Various explanations for the hat have been offered. One asserts that "steeple-crowned" hats were put on the heads of witches before they were burnt at the stake, possibly so that the holy symbol would attract the forgiveness of Heaven. Others associate it with the persecution of Quakers in America, or with the mediæval persecution of Jews in Europe, and link it with the traditional form of the dunce's cap, which has no brim (Jensen n.d.). The high point also evokes images of masked penitents in Spanish religious processions, and of the Klu Klux Klan.

In illustrated books for children published in the early nineteenth century, the characteristic hat is associated with old women wearing outdated costume, with no clear implication that they are witches (pl. 15). The holdings of the Osborne Collection of Early Children's Books at the Toronto Public Library include many with woodcut illustrations, including The Talking Bird; or, Dame Trudge and Her Parrot, printed in London in 1806 and Mother Hubbard and Her Dog, a chapbook published in Derby in about 1830 (De Vries 1965). Dame Trudge is shown wearing a black hat with a broad brim and a pointed crown, but the antics of her animals are attributed to the agency of the parrot, and not to any witchcraft on her part. The same is true of Mother Hubbard and her dog, but clearly the association between old women and performing animals stands in place of the idea of witches and their familiars.

The more direct association of the pointed hat with the female witch came in the early decades of the twentieth century with such illustrators as Arthur Rackham who gave them to some exceedingly repellent old women, but also to at least one pretty young witch riding a broomstick, and to Cinderella's fairy godmother. He also attributed them to a male wizard in his Sleeping Beauty, but that was as late as 1920. Rackham's work was equally popular and influential on both sides of the Atlantic, and although he was pre-eminent in the field, he was not alone.

The simultaneous appearance of North's sinister steeples and the children's book illustrations that have formed the mental association with them make it unlikely that such a connection was present in the mind of Alexander North. His devout Anglicanism with a probable tendency towards the Anglo-Catholic was far removed from any intention of satire or sacrilege. Our response to his work is a powerful demonstration of the validity of an associationist basis for aesthetic appreciation. The question remains: what was in North's mind when he drew those striking profiles?

North was clearly aware of the work of Viollet-le-Duc, and this awareness clearly went beyond a knowledge of the French master's mediæval reconstructions. The oddity of his more original designs clearly links him to other contemporary influences, notably to what has come to be known, principally in literature and painting, as Decadence. It was the time of Huysmans, Paul Verlaine, Aubrey Beardsley and Oscar Wilde. I am not aware of any authoritative attempts to identify a Decadent architecture, so I offer the topic to anyone in search of a subject for a $\mathrm{PhD}$. 
Think about the possible links between the graphic work of Aubrey Beardsley, which might bring a blush to the cheek of a Victorian young person, and that of Arthur Rackham, for whose illustrations she, a generation later, would have been the principal consumer. Stephen Romer, an English academic in a French University, has recently reminded us of the complexity of the fin de siècle in which Alexander North formed his ideas:

It was a period which saw, in no particular order, Bell's telephone, Edison's incandescent light-bulb, Pasteur's vaccines, the Eiffel Tower, [...] the first great department stores, free secular primary education for all, the legalization of divorce, the French can-can, child labour laws, anarchy, and the Dreyfus affair.

(Romer 2013 p. xiv)

Romer is looking at the era from a Continental perspective, but the flow of influences back and forth across the Channel was never interrupted, even by seventy years of conflict with revolutionary France, and North was working in the era of the Entente Cordiale. French decadence was alive and well in England, although mitigated in public at least by the Lord Chamberlain's regulations, the imprisonment of Oscar Wilde, academic conventions in the visual arts, literary censorship, and laws that made it necessary to import contraceptive devices as French letters. It was only a few years since the Ripper murders had torn the veil from the benign self-image of Victorian society. The darker underside of the Edwardian summer epitomised by Edwin Lutyens's mansions set in gardens by Gertrude Jekyll was more publicly evident than before. Did it find expression in architecture of the time, and particularly in church architecture, built to prevail against the "Gates of Hell"?
North would have been fully aware that mediæval churches were frequently provided, particularly on the outside, with carved images of pagan origin, some of them judged impious and obscene by later generations, "under the general rule that the gods of an older religion become the devils of a new faith" (Anderson 1988, p. 105). Those carvings that are more explicit than merely decorative have been variously understood as intended to ward off evil, or to show that it remains external, unable to penetrate the sanctuary within; they may represent persisting adherence to an older cult, or like some of the indoor carvings on misericords, a subversive wish to deride the clergy. Some may result from the mere fancy of the stone-carver, employed to embellish a fane, and paid by the day.

For the whole of the colonial nineteenth century, the few carved devices that appeared on churches in Tasmania were conventionally pious or neutrally vegetable. Other than the Catholic bishops' mitred monographs on some of Henry Hunter's churches, the only arguable exceptions are the heads that form the drips of the hood moulding above the door of St Luke's Church at Bothwell, carved by Daniel Herbert in about 1830, which Norman Laird held to be Celtic deities on the doubtful evidence of their head-dress; the male has a fine set of the muttonchop whiskers that were becoming fashionable at the time, perhaps caricaturing a member of the colonial establishment (Laird 1971).

In his first major essay in Arts and Crafts Gothic Revival, Alexander North gave the exterior of Holy Trinity some more explicit intimations of evil, but they carry a hidden message of salvation. The drips of the moulding over the rose window of the north transept are contorted and

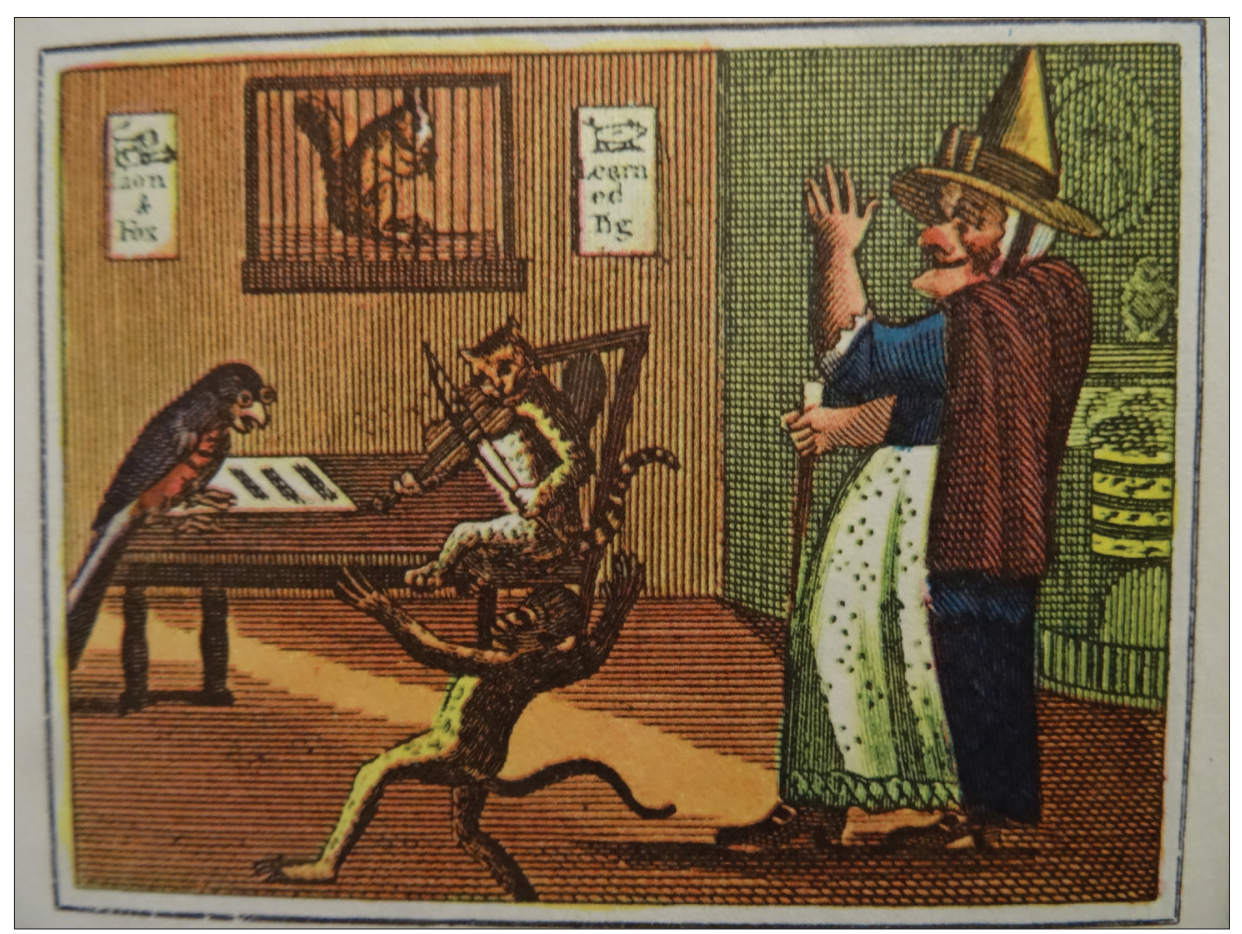

Plate 15 - Dame Trudge and her Parrot, J. Harris at the Original Juvenile Library, London 1808 
foliated animals with huge haunches, reptilian tails and dog-like heads; antipodean monsters that owe something to the kangaroo as well as to the salamanders of European imagination. They are curiously ambiguous creations, for salamanders with their mythical ability to resist and quench fire were adopted in the middle ages as symbols of invincible faith, but here they are snarling like demons. In a similar situation on the south side, beside a window lighting the organ loft, the monsters are no longer foliated but winged, and so are their larger fellows on the kneelers of the east gable. They are not dragons but devils, for their wings are feathered and not webbed; in some biblical mythology, devils are held to be rebellious angels. These, fiercely snarling as they appear to be about to plunge, have had their wings clipped. These demons are not merely fallen angels; they are not swooping to encompass the damnation of the parishioners, but falling because they have been defeated, their powers curtailed.

These carvings, like the foliated decorations elsewhere on the church, were designed in detail by North, and realised by Hugh Cunningham (1858-1945). From the carvings, we can infer that North did not have a mediæval sense of the diabolical, but a more suitably moderate Anglican one. But he was a Churchman devout enough to build a chapel in his own house, so he probably had a personal sense of a cosmic conflict between good and evil. Yet his salamanders writhe because they are entangled with Art Nouveau Gothic foliage and not because they are enduring the fires of Hell; his devils are malevolent, but they will not prevail.

On a weatherboarded country church, such apotropaic devices were not affordable, but a splay-foot spire clad in sheet metal could perhaps provide shelter from more than rain, and at a time when Anglican certainties were under question as never before.

\section{REFERENCES}

Anderson 1988: The Rise of the Gothic. Dorset Press, New York: $105 \mathrm{pp}$.

Andrews, B. 2001: Australian Gothic: The Gothic Revival in Australian Architecture from the 1840s to the 1950s. Miegunyah Press, Melbourne: 135 pp.

Boyce, P. 2012: God and the City: A History of St David's Cathedral, Hobart. St David's Foundation, Hobart: 102 pp.

Branagan, J.G. 1989: History of Holy Trinity Church, Launceston. The author, Launceston: $37 \mathrm{pp}$.

Coogan, W. \& Co. 1913, catalogue, Launceston. (facsimile, Hobart 1994): pp 1, 2, 4, 35, 49, 50.

Crook, J.M. 1987: The Dilemma of Style: Architectural ideas from the Picturesque to the Post-Modern. John Murray, London: pp. 12, 226.

Cubitt, J. 1870: Church Design for Congregations: its Development and Possibilities. Smith, Elder and Co., London: 156 pp.

Cubitt, J. 1884: Wren's Work and its Lessons. Contemporary Review 46: 97-111.

Cubitt, J. 1892: Popular Handbook of Nonconformist Church Building. James Clarke \& Co., London: 121 pp.

De Vries, L. (ed.) 1965: Flowers of Delight culled [...] from the Osborne Collection of Early Childrens' Books. Dennis Dobson, London: 230 pp.
Donald, E.B. 1995: The French Farmhouse. Little, Brown and Company, London: 200 pp.

Foy \& Gibson Pty. Ltd. 1923: catalogue, Melbourne: 129, 134, 158-159.

Gill, J.S. 2010: Holy Trinity Church, Launceston: A History from 1838. The author, Launceston: $24 \mathrm{pp}$.

Green, A. 2006: The Home of Sports and Manly Exercise: Places of Leisure in Launceston. Launceston City Council, Launceston: 48-49.

Henslowe, D.I. 1978: Our Heritage of Anglican Churches in Tasmania. Diocese of Tasmania, Hobart: 107 pp.

Jensen, G. n.d.: cited by Venters, L. www.widdershins.org/vol6iss8/ oestora01.07.hhtp (accessed 1 October 2013)

Laird, N. 1971: Daniel Herbert and his Icons In Greener, L. \& Laird, N. (eds), Ross Bridge and the Sculpture of Daniel Herbert. Fullers Bookshop, Hobart: 134-135 pp.

Launceston Examiner 1886: Ecclesiastical Architecture, 16 June 1886.

Lavenu, M. \& Mataouchek, V. 1999: Dictionnaire d'Architecture. Jean-Paul Gisserot, Paris: p. 44.

Maidment, J. 1981: Gothic Visionary: Alexander North 18581945. Trust News 9 (3): 10-13. National Trust of Australia (Victoria), Melbourne.

Maidment, J. 1982: Alexander North and His Work in Tasmania', Newsletter No. 80, December 1982, 1-2. National Trust of Australia (Tasmania), Launceston.

Maidment, J. 1988: North, Alexander 1858-1945. In Australian Dictionary of Biography Vol. 11, Melbourne University Press, Melbourne: 38-39.

Maidment, J. 2012: North, Alexander. In Goad, P. \& Willis, J. (eds), The Encyclopedia of Australian Architecture. Cambridge University Press, Melbourne: 503-504.

Masters, H.A. 1900: Entry in Cyclopedia of Tasmania, Maitland and Krone, Hobart: Vol II, 99 pp.

Miley, C. 1987: Beautiful and Useful: The Arts and Crafts Movement in Tasmania. Queen Victoria Museum and Art Gallery, Launceston: 54-55.

Morris-Nunn, R. \& Morris-Nunn, M. 1989: Pure Air and Lovely Aspect. In Howells, T. and Nicholson, M. (eds), Towards the Dawn: Federation Architecture in Australia 1890-1915. Hale \& Iremonger, Sydney: 91.

Neale, A. 2012: Masters, A. Harold In Goad, P. \& Willis, J. (eds) The Encyclopedia of Australian Architecture. Cambridge University Press, Melbourne: 433-434.

North, A. 1882: The Truthful Treatment of Brickwork. Proceedings of the Australasian Association for the Advancement of Science, January 1882: 912-913.

North, A. 1891: Notes on Tasmanian Ferns, extracts from a paper read at a meeting of the Natural Science Association of Northern Tasmania, 29 October 1891, printed in The Tasmanian, 7 November 1891, reprint n.d.

North, A. 1892: The truthful treatment of brickwork. Proceedings of the Australasian Association for the Advancement of Science, Proceedings of Sections: Architecture and Engineering 1892: 12-13.

North, A. 1904: The Economic Aspect of Tasmanian Forests. The Transactions of the Australasian Association for the Advancement of Science, Dunedin, January 1904, Government Printer, Wellington: 1-14.

North, A. 1905: Rural Churches. Proceedings of the Australasian Association for the Advancement of Science 1905; reprint, upaginated.

Nyman, L.C. 1988: The West Tamar People. The author, Launceston: 186-187.

O'Neil, F. 2000: Federation Architecture. The New Federalist: The Journal of Australian Federation History No. 5: 76.

Pevsner, N. 1936, 1947: Pioneers of Modern Design. Penguin Books, Harmondsworth, Middlesex: pp. 156-157.

Pevsner, N. 1952: The Buildings of England: London except the Cities of London and Westminster. Penguin Books, Harmondsworth, Middlesex: p. 230. 
Pevsner, N. 1968: The Sources of Modern Architecture and Design. Thames and Hudson, London: 220 pp.

Proverbs, B. 1988: From the Beginning: A History of the Launceston Technical College 1888-1988. Launceston College of TAFE, Launceston: 30, 38

Ratcliff, E.V.R. \& Ratcliff, F.B. 2005: Perfection in a Small Sphere: St Vincent's Hospital, Launceston 1944 to 1997 and beyond. St Vincent's Private Hospital, Launceston: chapter 2.

Romer, S. 2013: Introduction to French Decadent Tales. Oxford University Press, Oxford: 288 pp.

Saunders, D. 1969: Domestic Styles of Australia's Federation Period: Queen Anne and the Balcony Style. Architecture in Australia August 1969: 655-662.
Smith, B. 1969: Review of J.M. Freeland, Architecture in Australia: A History, Historical Studies, October 1969: 90.

Stanshall M.E.J., Hingston, R.E., Miller, D.J. \& Andrews, R.J. 1976: Tasmanian Methodism 1820-1975. Methodist Conference of Victoria and Tasmania, Launceston: 40.

The Examiner (Launceston) 1945: Obituary, 2 June 1945.

Willis, J. \& Goad, P. 2008: A Myth in the Making: Federation Style and Australian Architectural History. In Leach, A., Moulis, A. \& Sully, N. (eds), Selected Essays on the Architectural History of Australia and New Zealand. University of Queensland Press, Brisbane: 139.

(accepted 7 November 2017) 